\title{
Assessment of Door Handles as Potential Reservoirs of Multidrug Resistant Staphylococcus aureus in Rivers State, Nigeria
}

\author{
Kome Otokunefor* and Nneoma Chukwunta \\ Department of Microbiology, Faculty of Science, University of Port Harcourt, P.M.B. 5323, \\ Port Harcourt, Nigeria \\ *Corresponding author
}

Keywords

Antibiotic

resistance, MDR, door handles, Nigeria, microbial contamination

\section{Article Info}

Accepted:

12 March 2021

Available Online:

10 April 2021
Door handles have especially been implicated as fomites with the propensity to transmit infectious agents dues to their crucial high touch role. Information on the role these play in the possible spread of multidrug resistant (MDR) pathogens is however limited. This study presents information on the possible role door handles in a tertiary institution in Rivers State, Nigeria may play as reservoirs of multidrug resistant strains of Staphylococcus aureus. A hundred door handles were sampled using the swab and rinse method involving sterile swab sticks, and samples processed by culturing of Mannitol Salt Agar. Presumptive characteristic colonies were then purified, their identities confirmed and antibiotic susceptibility determined using standard microbiological tests. Results revealed a 35\% occurrence of Staphylococcus aureus on the sampled door handles, which showed varying levels of resistance to test antibiotics. A 100\% resistance was noted against 5 different antibiotics and the lowest resistant $(2.9 \%)$ noted against of loxacin. Only 5 antibiograms were represented within the isolates, with AUG-CAZ-CRX-CXC-ERY exhibited by $60 \%$ (21/35) of isolates. A $100 \%$ of isolates were resistant to 3 and more drug classes indicating a $100 \%$ occurrence of multidrug resistance within the $S$. aureus isolates detected. This study reveals a high association of multidrug resistant Staphylococcus aureus with non-toilet door handles. This is of major public health interest as it indicates a potential risk these high touch surfaces could play as reservoirs for the spread of multidrug resistance.

\section{Introduction}

Despite remarkable advances in medical research aimed at prevention and therapy of infectious diseases during the 20th century, infectious diseases still remain one of the leading causes of death worldwide. Fomites have been shown to play a critical role in the transmission of these diseases. Among these inanimate objects with a propensity to transmit disease pathogens, door handles are especially implicated. This is possibly due to the crucial high touch role they play in human activities as well as their smooth non-porous 
composition which is associated with higher levels of transmission (Odigie et al., 2017). Several studies in Nigeria have reported the association of door handles with a wide array of potentially pathogenic bacteria (Nworie, et al., 2012; Onwubiko and Chinyeaka, 2015; Odigie et al., 2017; Omoruyi and Ekhaise, 2017;Akinrotoye et al., 2018;Alonge et al., 2019). Majority of these studies described Staphylococcus aureus as one of the top two leading organisms associated with door handles. A number of studies explored the association of door handles with drug resistant organisms (Lincy et al., 2016; Omoruyi and Ekhaise, 2017; Abiose 2019). Reports which explored the association between multidrug resistant(MDR) bacteria and door handles however were limited. The scourge of multidrug resistance bacteria has been on the increase worldwide and Staphylococcus aureus is one of the key bacteria associated with this scourge due to its ability for rapid acquisition of resistance determinants (Kot et al., 2020). MDR S. aureus has however been linked with a worse prognosis, increased hospital stay and mortality. Nasal carriage of MDR strains of $S$. aureus has however been widely reported in apparently healthy individuals (Arali et al., 2016; Kadariya et al., 2019; Kateete et al., 2019; Onanuga et al., 2021). Considering the key role door handles play as fomites, there therefore exists the potential that they play a role as possible reservoirs of MDR $S$. aureus. This study therefore set out to explore the possible role door handles in a tertiary institution in Rivers State, Nigeria may play as reservoirs of multidrug resistant strains of Staphylococcus aureus.

\section{Materials and Methods}

\section{Sample collection and processing}

A hundred door handles in a tertiary institution in Rivers State (Nigeria) were sampled using the swab and rinse method (Reynolds et al., 2005) involving sterile swab sticks. Swab samples were then immediately transported to the Medical Microbiology laboratory of the Department of Microbiology, University of Port Harcourt. Samples were then processed by culturing on Mannitol Salt Agar.

\section{Isolation and Identification of $S$. aureus}

Following culture on Mannitol Salt Agar, colonies characteristic of $S$. aureus (yellow pigmented) were subcultured to Nutrient agar and their identities confirmed using relevant previously described biochemical tests (Cowan and Steel 1985; Cheesbrough 2006).

\section{Antimicrobial Susceptibility Testing}

Antimicrobial susceptibility testing was then carried out on isolates using the previously described disc diffusion test method (Bauer $e t$ al., 1966).

In brief, a standard inoculum ( $0.5 \mathrm{McFarland})$ was plated out on a Mueller Hinton plate using a sterile swab stick to produce a uniform lawn of growth. Test multi-antibiotic discs were then applied following a 15 minute preincubation period at room temperature. Subsequent to a 24 hour incubation at $37^{\circ} \mathrm{C}$, diameter readings for the zones of inhibition were determined and each organism tagged as susceptible or resistant to the antibiotic based on a standard interpretative chart (NCCLS 2000).

\section{Determination of MAR Index}

The multiple antibiotic resistant (MAR) index for each isolate was then calculated using the $\mathrm{a} / \mathrm{b}$ formula (Cookey and Otokunefor, 2016), where " $a$ " is the total number of antibiotic isolate is resistant to and "b" is the total number of test antibiotics. 


\section{Assessment of Multidrug Resistance}

Antibiograms of each individual isolate was assessed and multidrug resistant organisms defined as organisms with resistance to 3 or more classes of antibiotics.

\section{Results and Discussion}

Following identification of the isolates, this study revealed a 35\% occurrence of Staphylococcus aureus on the sampled door handles. These isolates showed varying levels of resistance to the test antibiotics (Fig. 1), with a $100 \%$ resistance noted against 5 different antibiotics and the lowest resistant $(2.9 \%)$ noted against ofloxacin.

An analysis of the antibiogram of each isolate revealed only 5 antibiograms represented within the isolates (Table 1). All isolates were resistant to 5 or more antibiotics, though no isolate was resistant to $100 \%$ of the antibiotics. One antibiogram (AUG-CAZCRX-CXC-ERY) was predominant, exhibited by $60 \%(21 / 35)$ of isolates.

All (100\%) isolates had high MAR index values, greater than 0.5 (Fig. 2). Majority $(60 \%)$ however had a 0.63 MAR index value. In agreement with the MAR Index values, a $100 \%$ of isolates were resistant to 3 and more drug classes indicating a $100 \%$ occurrence of multidrug resistance within the $S$. aureus isolates detected. Variations however existed in the exact number of drug classes the MDR isolates were resistant to (Fig. 3). The MDR isolates could be divided into 2 based on number of drug classes and majority of isolates $(80 \%)$ were resistant to 3 drug classes.

Hospital environments were initially identified as potential active reservoirs for the dissemination of multidrug resistant pathogens (Sexton et al., 2006; Chemaly et al., 2014). In more recent years however, non-hospital sources have increasingly been identified also as reservoirs for some MDR pathogens (van Duin and Paterson, 2016). This study which set out to explore the role non-hospital door handles may play as potential reservoirs of multidrug resistant $S$. aureus, first identified a $35 \%$ occurrence of S. aureus from the 100 door handles sampled. Majority of studies exploring this, focus on toilet door handles or hospital associated door handles (Agbagwa and Onyebule, 2018; Bhatta et al., 2018; Odigie et al., 2018; Alonge et al., 2019; Tefera et al., 2019). For the few studies exploring general door handles, the rate observed in this study was higher than severally of the reports. These studies noted occurrence rates ranging from $10.5 \%$ to $26 \%$ (Amala et al., 2015; Onaolapo et al., 2015; Owaku et al., 2018; Abiose 2019;Akinrotoye et al., 2019) but lower than the $56.48 \%$ and $66.7 \%$ described in a 2017 study(Akinjogunla and Divine-Anthony, 2017). S. aureus in a known commensal carried in the nasopharyngeal region by up to $30 \%$ of the human population (Hanson et al.,2017). The presence of this organism on door handles could therefore represent poor hygiene practices involving contact of the hand and nose and a lack of proper hand hygiene.

These isolates detected in this study however revealed high levels of resistance. This was similar to the study by Akintoroye and colleagues (Akinrotoye et al., 2019) which reported a $100 \%$ resistance to three different antibiotics.

The Akinrotoye study had looked at multiple types of door handles, including toilet door handles. The results were also similar to a previous studying reporting on antibiotic resistance of $S$. aureus obtained from nontoilet door handles in Nasarawa State University (Owaku et al., 2018). 
Table.1 Antibiogram of Isolates

\begin{tabular}{|l|c|c|c|}
\hline S/No & Antibiogram & $\begin{array}{c}\text { No of } \\
\text { Isolates }\end{array}$ & $\begin{array}{c}\text { No of Resistant } \\
\text { classes represented }\end{array}$ \\
\hline $\mathbf{1 .}$ & AUG-CAZ-CRX-CXC-ERY & 21 & 3 \\
\hline $\mathbf{2 .}$ & AUG-CAZ-CRX-CTR-CXC-ERY & 7 & 3 \\
\hline $\mathbf{3 .}$ & AUG-CAZ-CRX-CXC-ERY-GEN & 5 & 4 \\
\hline $\mathbf{4 .}$ & AUG-CAZ-CRX-CTR-CXC-ERY-OFL & 1 & 4 \\
\hline $\mathbf{5 .}$ & AUG-CAZ-CRX-CTR-CXC-ERY-GEN & 1 & 4 \\
\hline
\end{tabular}

Key: Augmentin (AUG),Ceftazidime (CAZ). Cefuroxime (CRX), Ceftriazone (CTR), Cloxacillin (CXC), Erythromycin (ERY), Gentamycin (GEN), Ofloxacin (OFL).

Fig.1 Resistance rates of isolates to test antibiotics

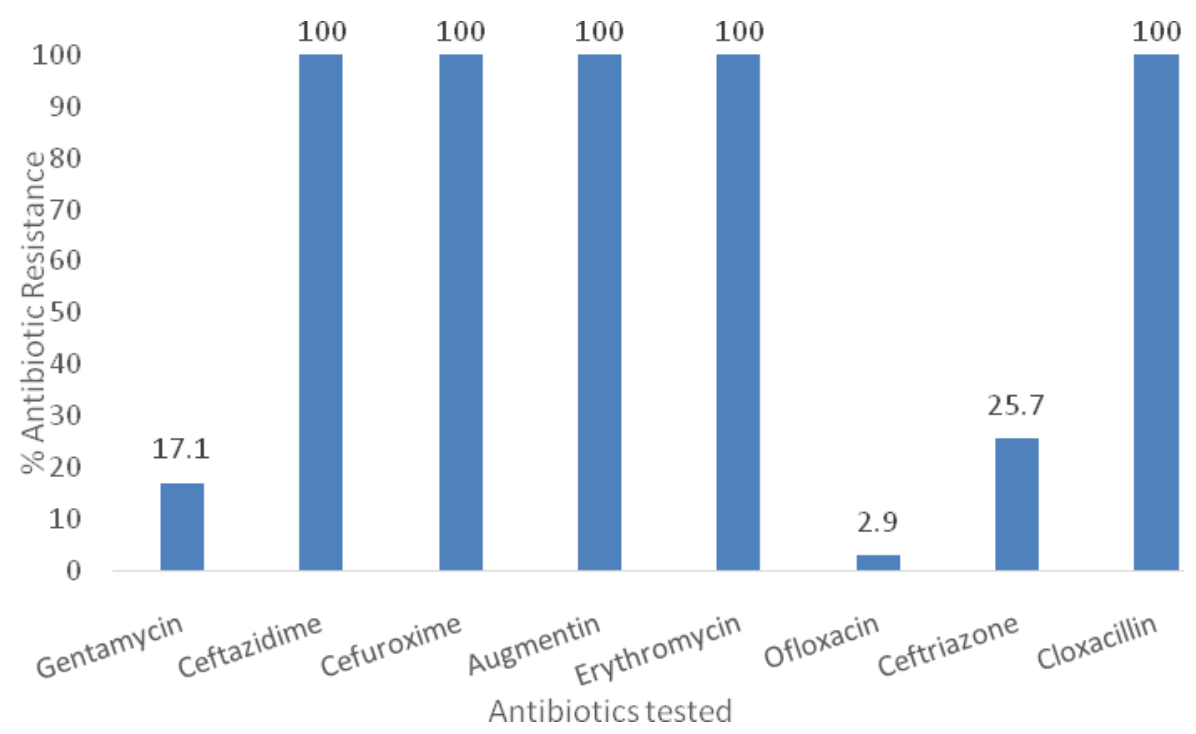

Fig.2 Distribution of isolates within MAR Indices

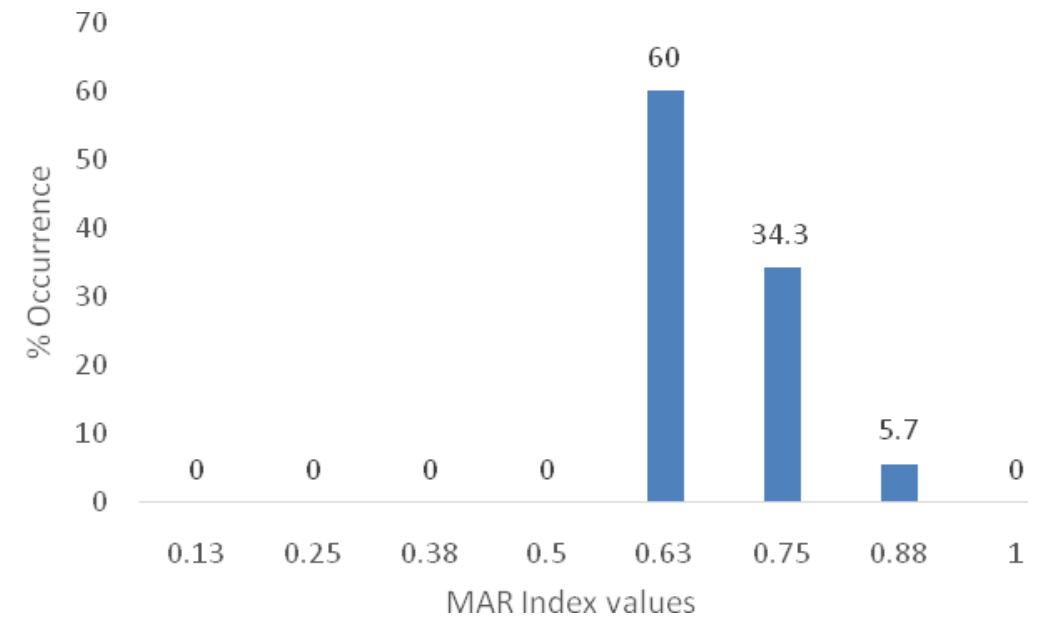


Fig.3 Distribution of isolates by resistance to the different classes of antibiotics

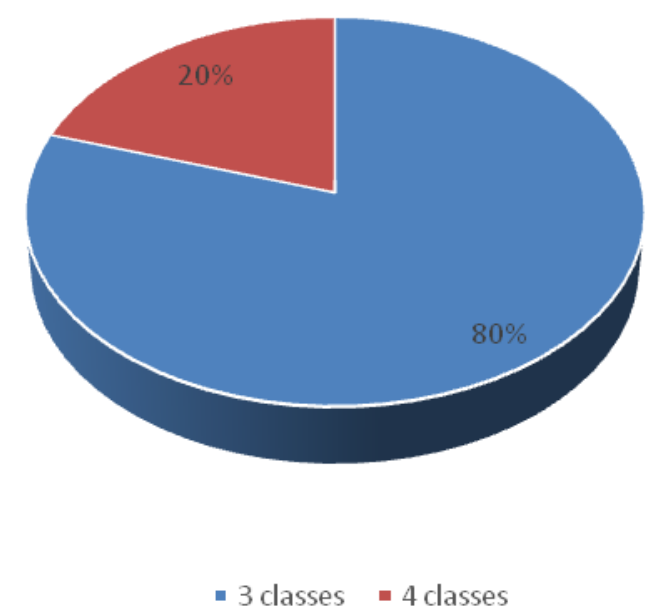

Owaku and colleagues noted high resistance rates (60\% and above) against the majority of antibiotics assayed (87.5\%). The results however differed from a report by Onwubiko and Chinyeaka studying door handles in a tertiary institution in Umuahia, which reported resistance rates lower than $40 \%$ against $44.4 \%$ of antibiotics tested (Onwubiko and Chinyeaka, 2015). Onaolapo and colleagues which looked specifically at non-toilet door handles had strikingly different results with isolates exhibiting sensitivity rates of $90 \%$ and above against six antibiotics (Onaolapo et al., 2015). Even when compared with studies focusing specifically on toilet door handles, results from this study were still much higher. Tefera and colleagues in a 2019 study surveying toilet handles in Ethiopia reported low resistance rates less than $50 \%$ against the majority of antibiotics (90.9\%) tested (Tefera et al., 2019), but similar high levels of resistance against penicillin. Alonge and colleagues assessing toilet door handles reported much lower resistance rates $(0 \%$ to $44.4 \%$ ) with majority of their isolates susceptible to the antibiotics tested (Alonge et al., 2019). These variations in susceptibility patterns could reflect source of microorganisms with respect to commensal versus pathogenic. Pathogenic bacteria are generally expected to have higher levels of drug resistance due to possible interactions with antibiotics as opposed to harmless commensals.

The high level (100\%) of MDR reported in this study in association with strains of $S$. aureus isolated from non-toilet door handles has been similarly been reported previously. A study by Badger-Emeka and colleagues in 2015 reported $100 \%$ of MDR in strains of $S$. aureus(Badger-Emeka et al., 2015). These isolates were however obtained from a collection of diverse sampling points referred to as "shared utility devices" which included other locations in addition to office and toilet door handles. Two studies on non-toilet door handles in tertiary institutions in other parts of Nigeria (Nasarawa and Zaria), also reported high levels of MDR $S$. aureus strains (Owaku et al., 2018; Onalapo et al., 2015). Owaku and colleagues reported MDR rates of $46.2 \%$ while Onalapo and colleagues reported a $70.6 \%$ rate of MDR. 
This study reveals a high association of multidrug resistant Staphylococcus aureus with non-toilet door handles. This is of major public health interest as it indicates a potential risk these high touch surfaces could play as reservoirs for the spread of multidrug resistance.

\section{References}

Abiose, O. F. 2019. Bacterial contamination of selected public toilet door handles within Adekunle Ajasin University Campus, Akungba-Akoko, Ondo State, Nigeria. Int. J. Sci.: Basic Appl. 43:76 $-86$.

Agbagwa, O. E., Onyebule, C. Q. 2018. Microbial population of Staphylococcus aureus from inanimate surfaces in a general hospital environment in Rivers State, Nigeria. J. Appl. Sci. Environ. Manage. 22(1):124 - 128 .

Akinjogunla, O. J., Divine-Anthony, O. 2017. Disinfectant susceptibility of bacteria isolates from door handles in a tertiary institution in Uyo, Akwa-Ibom state. Int. J.Innov. Agric. Biol. Res. 5(1):18 31.

Akinrotoye, K. P., Bankole, M. O., Oluwole, S. 2018, Occurrence of pathogenic bacteria on public surfaces within community schools in Abeokuta Environs, Ogun State. J. Environ. Treat. Technol. 6(3):47 - 52.

Akinrotoye, K. P., Bankole, M. O., Akinduti, P.A., Lanlokun, O. A. 2019. Antibiotic resistance profiles of Staphylococcus aureus isolated from fomites in community schools within Abeokuta environs leading to detection of MRSA. Biosci. Methods. 2(2): 1 - 19.

Alonge, O. O., Auwal, B. M., Aboh, M. I. 2019. Bacterial contamination of toilet door handles on Baze University campus Abuja Nigeria. African J.Clin.
Exp.Microbiol. 20(1):35 - 41.

Amala, S. E., Ade, A. J., Bloomfield, F. 2015. Bacteria associated with toilets and office lock handles. Int. J. Epidemiol. Infect. 3(1): 12 - 15.

Arali, S. M., Kulkarni, V., Manjula, N. G., Gaddad, S. M., Jayaraj, Y.M., Shivannavar, C. T. 2016. Prevalence and antibiotic susceptibility profile of MRSA isolated from the anterior nares of school going children in Gulbarga. Int. J. Med. Sci. Public Health. 5(04): $620-626$.

Badger-Emeka, L. I., Al-Sultan, A. A., AlDehailan, H. S., Al-Humini, N. K., AlNajja, F. A., Al-Farhan, H. M. 2015. Potential pathogenic bacterial contaminants of shared utility devices in a university setting at Al-Hofuf, Saudi Arabia. African J.Microbiol. Res. 9(41): 2139 - 2144.

Bauer, A. W., Kirby, W. M. M., Strerris, J. C., Turk, M. $1966 . \quad$ Antibiotic Susceptibility Testing by a Standard Single Disk Method. American J. Clin. Pathol. 45: 493 - 496.

Bhatta, D. R., Hamal, D., Shrestha, R., Subramanya, S. H., Baral, N., Singh, R.K., Nayak, N., Gokhale, S. 2018. Bacterial contamination of frequently touched objects in a tertiary care hospital of Pokhara, Nepal: How safe are our hands? Antimicrob. Resist. Infect. Contr. 7(1):1-6.

Cheesbrough, M. 2006. District laboratory practice in tropical countries Part II. Cambridge University Press, UK.

Chemaly, R. F., Simmons, S., Dale, Jr C., Ghantoji, S. S., Rodriguez, M., Gubb, J., Stachowiak, J., Stibich, M. 2014. The role of the healthcare environment in the spread of multidrug-resistant organisms: update on current best practices for containment. Ther.Adv.Inf.Dis. 2(3-4):79 - 90.

Cookey, T. I., Otokunefor, K. 2016 Poultry 
environment as a reservoir of antimicrobial resistant bacteria: a Nigerian story. Br.Microbiol. Res. J. 17(1):1 - 11 .

Cowan, S. T., Steel, K. J. 1985. Manual for the identification of medical bacteria, 4th edition. London: Cambridge University Press, UK.

Hanson, B. M., Kates, A. E., Mills, E., Herwaldt, L. A., Torner, J. C., Dawson, J. D., Smith, T. C. 2017. The oropharynx as a distinct colonization site for Staphylococcus aureus in the community. bioRxiv. 137901.

Kadariya, J., Thapaliya, D., Bhatta, S., Mahatara, R.L., Bempah, S., Dhakal, N., Smith, T.C. 2019. Multidrugresistant Staphylococcus aureus colonization in healthy adults is more common in Bhutanese refugees in Nepal than those resettled in Ohio. BioMed Res. Int. 2019: ID 5739247.

Kateete, D. P., Asiimwe, B. B., Mayanja, R., Mujuni, B., Bwanga, F., Najjuka, C. F., Källander, K., Rutebemberwa, E. 2019. Nasopharyngeal carriage, spa types and antibiotic susceptibility profiles of Staphylococcus aureus from healthy children less than 5 years in Eastern Uganda. BMC Infect. Dis. 19(1): 1 - 10 .

Kot, B., Wierzchowska, K., Piechota, M., Grużewska, A. 2020. Antimicrobial resistance patterns in MethicillinResistant Staphylococcus aureus from patients hospitalized during 20152017 in hospitals in Poland. Med.Princ.Pract.29:61 - 68 .

Lincy, M., Vidhya, A., Ali, P. S., John, J. 2016. Determination of bacterial and fungal loads and antibiotic susceptibility testing of bacteria isolated from public toilet door handles in Vellore district, Tamil Nadu, India. Int J Res Biosci. 5(4):69 - 78.

National Committee for Clinical Laboratory
Standards. Performance standards for antimicrobial susceptibility tests; Approved standard. 7th ed. M2-A7. National Committee for Clinical Laboratory Standards, Wayne, PA; 2000.

Nworie, A., Ayeni, J. A., Eze, U. A., Azi, S. O. 2012. Bacterial contamination of door handles/knobs in selected public conveniences in Abuja metropolis, Nigeria: A public health threat. Continental J. Med. Res. 6(1):7 - 11.

Odigie, A. B., Ekhiase, F. O., Orjiakor, P. I., Omozuwa, S. 2017. The role of door handles in the spread of microorganisms of public health consequences in University of Benin Teaching hospital (UBTH), Benin city, Edo state. Pharm. Sci. Technol. 2(2):15 - 21 .

Odigie, A. B., Ekhaise, F. O., Orjiakor, P. I., Nwadibe, E. C., Toba, O. A., Kenneth, O. C. 2018. Antibiotic susceptibility profile of bacteria isolated from door handles of University of Benin Teaching Hospital, Benin City, Edo State, Nigeria. J. Health Environ. Res. 4(1):35 - 41 .

Omoruyi, N. B., Ekhaise, F. O. 2017. The role of door handles in the proliferation of microorganisms of public health interest in male student hostels, University of Benin, Ugbowo Campus, Benin City, Nigeria. Nigerian Res. J. Eng. Environ. Sci. 2(1): $248-258$.

Onaolapo, J. A., Afolabi, O. E., Igwe, J. C. 2015. Incidence and antibiotic susceptibility profile of Staphylococcus aureus on door handles in Ahmadu Bello University, Zaria. J. Trop. Dis. 4(184):2.

Onanuga, A., Adamu, O. J., Odetoyin, B., Hamza, J. A. 2021. Nasal carriage of Multi-drug resistant Panton Valentine Leukocidinpositive Staphylococcus aureus in healthy individuals of 
Tudun-Wada, Gombe State, Nigeria. African J. Inf. Dis. 15(1):24 - 33.

Onwubiko, N. E., Chinyeaka, A. H. 2015. Isolation and identification of bacterial contaminants from door handles in a tertiary institution in Umuahia, Abia state, Nigeria. Nigerian J.Microbiol. 29:3139-3147.

Owaku, G., Oti, V., Tsaku, P., Ekeleme, K., Anumnu, A., Anzaku, S. 2018. Antibiotic susceptibility profile of Staphylococcus aureus from door handles in Nasarawa State University, Keffi, Nigeria. GSC Biolog. Pharm. Sci. 2(2): $033-039$.

Reynolds, K. A., Watt, P. M., Boone, S. A., Gerba, C. P. 2005. Occurrence of bacteria and biochemical markers on public surfaces. Int. J. Environ. Health Res. 15(3):225 - 234.
Sexton, T., Clarke, P., O'Neill, E., Dillane, T., Humphreys, H. 2006. Environmental reservoirs of methicillin-resistant Staphylococcus aureus in isolation rooms: correlation with patient isolates and implications for hospital hygiene. J. Hosp. Infect. 62(2):187 - 194.

Tefera, M., Abraham, Y., Tora, A. 2019. Determination of Staphylococcus aureus isolates and their antimicrobial susceptibility pattern from toilet door handles of hospitals and secondary schools in Sodo Town, Southern Ethiopia. Int. J. Res. Studies Biosci. 7(4): $14-22$.

van Duin, D., Paterson, D. L. 2016. Multidrug-resistant bacteria in the community: Trends and lessons learned. Infect.Dis.Clin. North Am. 30(2), 377-390.

\section{How to cite this article:}

Kome Otokunefor and Nneoma Chukwunta. 2021. Assessment of Door Handles as Potential Reservoirs of Multidrug Resistant Staphylococcus aureus in Rivers State, Nigeria. Int.J.Curr.Microbiol.App.Sci. 10(04): 224-231. doi: https://doi.org/10.20546/ijcmas.2021.1004.022 